\title{
Ethnomedicinal Plants Used by Batak Angkola Subethnic of Bulumario Village, Sipirok, South Tapanuli, North Sumatera
}

\author{
Khairissa Trisliani Asmara ${ }^{1 *}$ Nisyawati $^{1}$ MarinaSilalahi ${ }^{2}$ \\ ${ }^{1}$ Biology Department, Faculty of Mathematics and Sciences, Universitas Indonesia, Jakarta, Indonesia \\ ${ }^{2}$ Biology Education Department Faculty of Teacher Training and Education Universitas Kristen Indonesia, Jakarta, \\ Indonesia \\ *Corresponding author. khairissatrislianyasmara@gmail.com
}

\begin{abstract}
Ethnobotany is interdisciplinary study of human and plants practical use. The study was conducted in Bulu Mario Village in Sipirok District, South Tapanuli. Bulu Mario Village is directly contiguous to the SibualBuali wildlife sanctuary. It has an area of about 3000 ha inhabited by 53 householders with a population of 1,319 people. The study was conducted to examine the extent of inhabitants' knowledge toward medicinal use of the plants. The data collection was done by doing field surveys, interviews, and participatory observation under ethnobotany study approach. The data were analyzed by descriptive analysis. Majority People in Bulumario Village are prefer using traditional medicine from plants when it comes to medical treatment. The locals' tradition regarding to various medicinal plants, how to harvest and apply it are all inherited by their ancestors. The people of Bulumariovillage have been used 65 species of medicinal plants belonging to 37 families for treatment.
\end{abstract}

Keywords: Ethnomedicine, medicinal plants, local knowledge, Bulu Mario.

\section{INTRODUCTION}

Indonesia is an archipelago consisting of approximately 17,000 islands. Geographical conditions are the reason for the creation of a rich biodiversity of flora and fauna on land and sea, so Indonesia is known as one of the 'Megabiodiversity' country [4]. In Indonesia there are 25,000-30,000 species of plants, more than 1,500 species of birds, 500-600 species of mammals, 8,500 species of fish and other animals in very large numbers [6] [13]. Various species of plants and wild animals like this are referred to as medicinal uses.

The utilization of plants for medication has been long known. As much as 80 percent of people in developing countries are relying on plants for their medication purpose [5]. The utilization of plants in Indonesia to preserve health has been long applied as civilization develops. One of the concrete evidences is the relief of medicinal plant in Borobudur Temple [10]. Every ethnicity in Indonesia has different perception on ethnomedicine, including about the utilization method of the plants as traditional medicine. This is influenced by the diversity of culture, tradition, and local wisdom of different ethnicities and regions [14].

There are many researchs about plant as traditional medicinal uses had been done in Indonesia, such as ethnomedicin study in the Kanum Tribe at Wasur Papua using 37 species of plants to treat 24 types of diseases [15], the BatakPhakpakSubethnic at SurungMersada used
128 species of plants to treat 24 types of diseases [11], the Batak Simalungun Subethnic used 92 species of medicinal plants [12], and people at SibanggorJulu Village, Mandailing Natal Regency are known to utilize 31 species of medicinal plants [7].

Bulumario Village is a village located in Sipirok District, South Tapanuli Regency, North Sumatra Province. Bulumario Village is a village directly adjacent to the Sibualbuali Nature Reserve. The people in Bulumario Village still upholds local wisdom, but detailed information regarding local wisdom in Bulumario village has not been widely identified. One of the local wisdom is utilization of medicinal plants.

The people of Bulumario Village still believe in natural medication made of natural resources from around the environment. The local people's knowledge in the utilization of medicinal plants shall be recorded to prevent it from being forgotten as the civilization develops. Therefore, ethnobotany research of medicinal plants in Bulumario Village is essential to save the people's knowledge on the species of plants and indirectly preserve that valuable plant. 


\section{MATERIAL AND METHODS}

\subsection{Time and Study Area}

This study was held on August-September 2019 at Bulumario village, Sipiroksubdistrict, South Tapanuli Regency, North Sumatera Province. Astronomically Bulumario village is at $01^{\circ} 35^{\prime} 23^{\prime \prime}$ NLand $099^{\circ} 12^{\prime} 33^{\prime \prime}$ EL. The distance from SipirokSubdistrict to Bulumario village is $9.3 \mathrm{~km}$. The inhabitants of Bulumario village are dominated by SubethnicBatakAngkola and the rest are SubethnicBatak Toba, BatakMandailing and BatakSimalungun. The main livelihoods of Bulumario people are sugar palm (Arengapinnata) farmers, Coffee (Coffeaarabica) \& (Coffearobusta) farmers and rice (Oryza sativa) farmers.

\subsection{Respondent}

In this study the respondent was native inhabitants who were aged $\geq 30$ years old and had knowledges about medicinal plants, such as traditional healer and people who had been their patients. The respondents consists of 45 people with 9 key informants and 36 general respondent. The key informants consist of 1 village head, 1 village secretary, 1 raja adat (Harajaon), 2 teachers, 2 traditional healer (Datu) and 2 pemangku adat (Hatobangun).

\subsection{Tools and Materials}

The tools used in research include logbooks, camera, plant identification books, and stationery. The materials used are $70 \%$ alcohol, camphor, observation sheet, questionnaire sheet, hanging label, plastic sample and newspaper.

\subsection{Procedure}

The researchs method that been used are interview and field observation. The interview object was key informant and general respondents obtained from the results of snowball sampling. Ethnobotany data collection was done by in-depth interview semi-structures method with questionnaire. The questions include the species of medicinal plants, the part of plants that been used, where the plants been found, the intensity of use and what type of disease that been treat. The data obtained were then analyzed qualitatively.

\section{RESULT AND DISCUSSION}

\subsection{Result}

The knowledge about medicinal plants is obtained by Bulumario people from several sources, but it mostly comes hereditarily. At Bulumario Village, there is a traditional healer that is known as "Datu". Datu is someone whom is believed to be able to cure various types of diseases. Based on the interview, it was found that Datu used several types of plants to cure the diseases. His knowledge on the medication was obtained from his parents, supernatural revelation or dream. Based on the results of interviews with 45 respondents, there were 65 plant species of medicinal plants belonging to 60 genera and 37 families (Table 1) used by SubethnicBatakAngkola for treatment. These 65 plant species are able to cure several disease categories such as gastrointestinal disease, fever-cold-cough,influenza, tumor/cancer, throat-nose-ear, skin and genital, wound- bleeding, internal disease, obstetrics and gynecology. 
Table 1. Medicinal plants used by the Angkola sub-ethnic in Bulu Mario Village, Sipirok, South Tapanuli

\begin{tabular}{|c|c|c|c|c|c|}
\hline Family & Latin name & Local name & $\begin{array}{l}\text { Plant part } \\
\text { used }\end{array}$ & Location & Use \\
\hline Acoraceae & Acoruscalamus & Salimbatuk & Rhizoma & Yard & $\begin{array}{l}\text { Cold, stomachache, } \\
\text { fever,bruised,cough, sprained }\end{array}$ \\
\hline \multirow[t]{3}{*}{ Alliaceae } & Allium сера & Bawangmerah & Bulb & Farm & Cold, massage oil \\
\hline & Allium sativum & Bawangputih & Bulb & Farm & Cold, influenza, massage oil \\
\hline & $\begin{array}{l}\text { Allium } \\
\text { Schoenoprasum }\end{array}$ & Bawangbatak & Bulb & Farm & Cold, wound, massage oil \\
\hline Amaryllidaceae & Crinum asiaticum & Oppuoppu & Bulb & Yard & Sprained \\
\hline \multirow[t]{3}{*}{ Arecaceae } & Areca catechu & Pining & Fruit & Farm & Wound, postpartum \\
\hline & Arengapinnata & Bargot & Nira & Farm & $\begin{array}{l}\text { Constipation, diarrhea, ulcer, } \\
\text { cold, fever, cough }\end{array}$ \\
\hline & Cocosnucifera & Harambir & Stem & Farm & Postpartum (Mararang) \\
\hline \multirow[t]{3}{*}{ Asteraceae } & Gynuraprocumbens & Sambungnyaw a & Leaf & Rice field & Constipation, diarrhea, \\
\hline & Blumeabalsamifera & Galinggang & Leaf & Farm & Itchy and skin disease \\
\hline & $\begin{array}{l}\text { Clibadiumsurinamens } \\
\text { E }\end{array}$ & Mardeka & Leaf & Farm & Wound, stomachache \\
\hline Balsaminaceae & Impatiens balsamina & Haturangga & $\begin{array}{l}\text { Leaf and } \\
\text { Stem }\end{array}$ & Farm & Bump, prevent pregnancy \\
\hline Begoniaceae & Begonia isopteran & Sanduduk & Leaf & Farm & Wound \\
\hline Campanulaceae & $\begin{array}{l}\text { Hippobromalongiflor } \\
\text { A }\end{array}$ & Pahitmata & Leaf & Yard & Eyes drop \\
\hline Casuarinaceae & Casuarinasumatrana & Anturmangan & $\begin{array}{l}\text { Stem/ran } \\
\text { ting }\end{array}$ & Hutan & Postpartum (Mararang) \\
\hline Caricaceae & Carica papaya & Botik & Leaf & Farm & Malaria, Postpartum \\
\hline \multirow[t]{3}{*}{ Compositae } & $\begin{array}{l}\text { Crassocephalumcrepi } \\
\text { Dioides }\end{array}$ & Haba-haba & Leaf & Yard & Itchy, stomachache \\
\hline & Galinsogapariviflora & Taya-tayababi & Leaf & Yard & Boil \\
\hline & Mikaniascandens & Siropakpara & Leaf & Yard & Wound, astma, stomachache \\
\hline Convolvulaceae & Ipomeabatatas & Saunggading & Leaf & Farm & Boil, fever \\
\hline Cucurbitaceae & Cucumissativus & Acimun & Fruit & Farm & Hypertension \\
\hline \multirow[t]{4}{*}{ Euphorbiaceae } & Heveabrasiliensis & Hapea & Latex & Farm & Anti-snake poison \\
\hline & Jatropacurcas & Jarak & Leaf & Farm & Stomachache, cold \\
\hline & Sapium sp. & Modanghunik & Bark & Hutan & Diarrhea \\
\hline & Aleoritesmoluccanus & Kemiri & Fruit & Farm & Hair blackening \\
\hline Irridaceae & Elleutherinebulbosa & Bawangdayak & Bulb & Farm & Cholesterol and hypertension \\
\hline Lauraceae & Cinnamomumverum & Kayumanis & Latex & Farm & Wound and boil \\
\hline \multirow[t]{2}{*}{ Leguminosae } & Mimosa pudica & Putrimalu & Leaf & Yard & Wound and boil \\
\hline & Spatholobuslittoralis & Bajakah & Stem & Hutan & Cancer \\
\hline Loranthaceae & Loranthus spp. & Sarindan & $\begin{array}{l}\text { Whole } \\
\text { plant }\end{array}$ & Farm & Asthma and blood streamer \\
\hline Mackinlayaceae & Centellaasiatica & Apapaga & Leaf & Yard & Hypertension, wound \\
\hline \multirow[t]{2}{*}{ Malvaceae } & Sidaacuta & Sibagure & $\begin{array}{l}\text { Whole } \\
\text { plant }\end{array}$ & Farm & Rheumatic \\
\hline & Hibiscus archeri & Bungaraya & Leaf & Yard & Fever \\
\hline Meliaceae & Lansiumdomesticum & Laccat & Bark & Farm & Stomachache and astma \\
\hline Moracea & Artocarpuselasticus & Torop & Stem & Hutan & Burn \\
\hline Musaceae & Musa paradisiaca & Pisang raja & $\begin{array}{l}\text { Fruit's } \\
\text { skin }\end{array}$ & Farm & $\begin{array}{l}\text { Wound, smallpox and breast } \\
\text { milk streamer }\end{array}$ \\
\hline Myrtaceae & Psidiumguajava & Jambuhorsik & Leaf & Farm & Diarrhea \\
\hline Nyssaceae & Litsea sp. & Kulim & Stem & Forest & Postpartum (Mararang) \\
\hline Phyllanthaceae & Saurobusandrogynus & Nasinasi & Leaf & Yard & Breast milk streamer \\
\hline
\end{tabular}




\begin{tabular}{|c|c|c|c|c|c|}
\hline Piperaceae & Piper betle & Burangir & Leaf & Yard & $\begin{array}{l}\text { Eyes drop, toothache, } \\
\text { postpartum }\end{array}$ \\
\hline \multirow[t]{4}{*}{ Poaceae } & Cymbopogoncitratus & Sanggar- sanggar & Stem & Farm & Toothache \\
\hline & $\overline{\text { Dactylisgloremata }}$ & Rumputoma & Leaf & Yard & Smallpox \\
\hline & Oryza sativa & Eme & Seed & $\begin{array}{l}\text { Rice } \\
\text { field }\end{array}$ & Herpes \\
\hline & $\begin{array}{l}\text { Pennisetumpurpureu } \\
M\end{array}$ & Rumputmanis & Leaf & Yard & Ulcer \\
\hline Podocarpaceae & $\begin{array}{l}\text { Podocarpusneriifoliu } \\
S\end{array}$ & Hotang & Fruit & Forest & Ulcer \\
\hline Primulaceae & Labisiapumila & $\begin{array}{l}\text { Rumputpedasd } \\
\text { as }\end{array}$ & Leaf & Yard & Accelerate baby's birth \\
\hline \multirow[t]{3}{*}{ Rubiaceae } & Uncariagambir & Gambir & $\begin{array}{l}\text { Fruit and } \\
\text { leaf }\end{array}$ & Farm & Diarrhea, ulcer \\
\hline & Coffearobusta & Kopi kampung & Seed & Farm & Rheumatic \\
\hline & Petungah spp. & Kopi kopi & Stem & Hutan & Pospartum (mararang) \\
\hline \multirow[t]{3}{*}{ Rutaceae } & Citrus aurantiifolia & Ute ruandg & Fruit & Yard & Cough \\
\hline & Citrus lemon & Ute ruandg & Fruit & Yard & Cough \\
\hline & $\begin{array}{l}\text { Zanthoxylumacantho } \\
\text { Podium }\end{array}$ & Sinyarnyar & Fruit & Hutan & Cold \\
\hline Salicaceae & Flacourtiarukam & Rukam & Fruit & Hutan & Toothache \\
\hline \multirow[t]{5}{*}{ Solanaceae } & Solanumlycopersicum & Torungasom & Leaf & Farm & Itchy \\
\hline & Solanumtorvum & Rimbang & Fruit & Yard & $\begin{array}{l}\text { Anti-bee poison, anti-snake } \\
\text { poison, stomachache }\end{array}$ \\
\hline & Capsicum anиum & Lasiakrara & Fruit & Farm & Toothache \\
\hline & Capsicum frutescens & Lasiaklamot & Fruit & Farm & Wound, Fever \\
\hline & Physalisangulata & Pultak-pultak & Leaf & Yard & Hernia \\
\hline \multirow[t]{2}{*}{ Thymelaeaceae } & Phaleriamacrocarpa & Mahkotadewa & Fruit & Yard & Hypertension \\
\hline & $\begin{array}{l}\text { Aquilariamalaccacen } \\
\text { Sis }\end{array}$ & Gaharu & Stem & Forest & Internal disease \\
\hline Vitaceae & Vitisgracilis & $\begin{array}{l}\text { Gagatanharim } \\
\text { au }\end{array}$ & Fruit & Forest & Tumor, cancer, stroke \\
\hline \multirow[t]{4}{*}{ Zingiberaceae } & Etlingeraelatior & Harias & Flower & Farm & Fever \\
\hline & Curcuma domestica & Hunik & Rhizome & Farm & Cold \\
\hline & Kaempferiagalanga & Hasior & Rhizome & Farm & Cold, massage oil \\
\hline & Zingiberofficinale & Pege & Rhizome & Farm & Cough \\
\hline
\end{tabular}


From the 65 species of medicinal plants, the plant part had been used as medicine include leaf, stem, rhizome, bulb, latex, bark, flower, fruit, seed anf whole plants. The uses of part plants depends on the need for treatment. The most widely used part of plants by the Bulumario people is leaf, which is $43 \%$ (Figure 1). Meanwhile medicinal plants are most commonly found in farms (Figure 2).

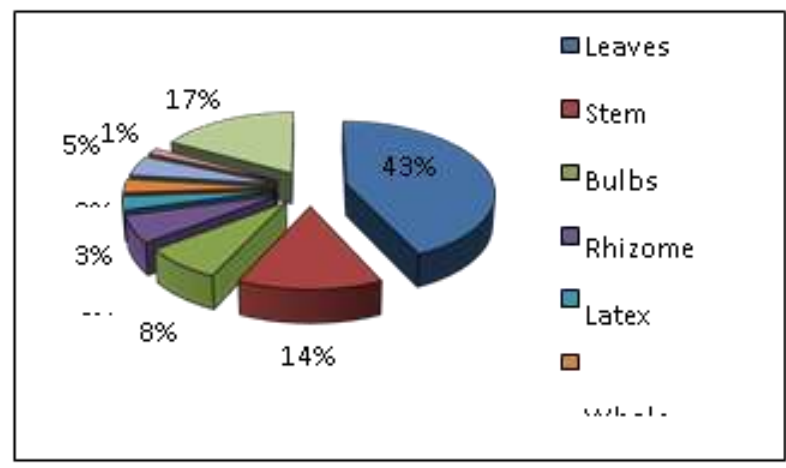

Figure 1. Percentage of plant part used

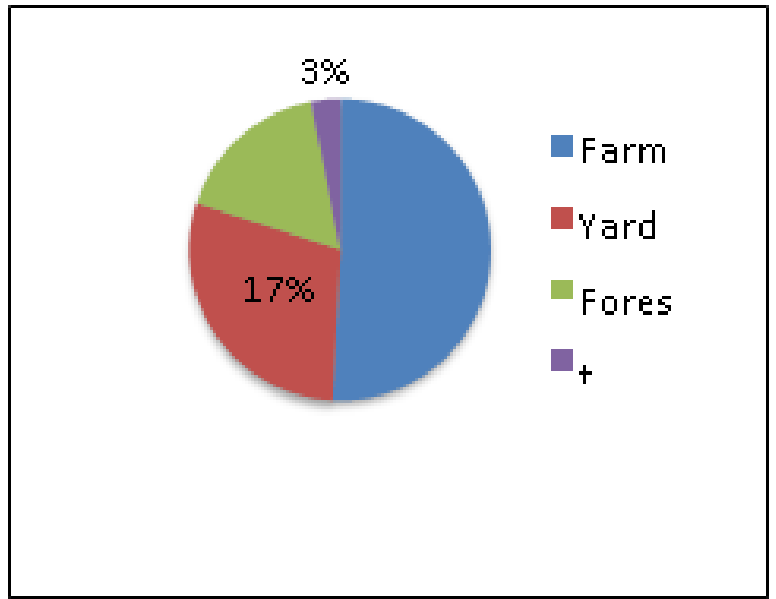

Figure 2. Percentage of location of medicinal plants

\subsection{Discussion}

However, as the civilization advances, the Bulumario people's belief on traditional medication keeps degrading. 65 species of plants are believed to be able to cure various diseases, this number is less compared to the other Batak sub- ethnicities. BatakPhakpakSubethnic used 128 species of plants to treat 24 types of diseases [11]

,BatakSimalungunSubethnic used 92 species of medicinal plants [12], BatakKaroSubethnic used 181 species 61 family as medicinal plants[1]. The small number of medicinal plants in bulumario caused of several factors such as the plants' availability, diversity of people's belief, culture, tradition and local wisdom. The previous research, that was conducted at Mandailing Natal Regency, which was dominated by BatakAngkola sub-ethnic, showed that there were only 31 species from 17 families of medicinal plants [7]. This further confirms that the BatakAngkolasubethnic indeed used a little medicinal plants. Bulumario people only use the plants as medicine in emergency or light diseases only, such as injured when farming, headache, stomachache, or colds. The reasons why people choose to use medicinal plants are because it is cheap, easy to find, and not dangerous to use [8].

The most common type of disease found in Bulumario village is wound. Because the majority of people in bulumario are farmers which mostly work with knives or machetes. So this causes the most commonly plant than been used by the people of bulumario is Siropakpara (Mikaniascandens). Almost all respondents mentioned this plant as a medicinal plant. Siropakpara is used by the people to heal wounds, such as wounds from knife or cleaver when farming. Some respondents also mentioned that siropakpara is able to cure stomachache. Siropakpara can be found in the yard, farm, or rice field's edges. Mikaniascandens is well known of its benefit. In India or Bangladesh, its leaf is extracted to cure various stomach problems and to heal wounds and bruises. Phytochemical result showed that Mikaniascandens contained vitamin A, C, B, flavonoid, steroid, alkaloid, tannin and saponin[3]. Mikaniascandensfrom the laboratory test result was not toxic and it was safe to use.

Furthermore, colds also common disease in Bulumario village because of the extremely cold weather conditions especially in the morning and evening. To treat colds many medicinal plants are used by people in bulumario, but the most frequently mentioned is Salimbatuk (Acoruscalamus). This plant usually be used to cure cold, cough, influenza and sprain. This plant also believed to be able to repel demons and cure posessed person. Salimbatuk is commonly found on sewer. Salimbatuk (Acoruscalamus) also as known as sweet flag has been long known as a medicinal plant since the last 2000 years. In Chinese medication, Acoruscalamusis recognized as a medicine for constipation and swelling. Traditional healers in India 'Ayurvada', use Acoruscalamus as a medicine for cold, asthma, sedative and cough; while in th West, it is used to cure digestive problems. Acoruscalamusknowncontains antimicrobial activity which inhibits the growth of bacteria, yeast or filamentous fungi, and it also contain antioxidant activity [2].

From the interview result, plant's part that is most commonly used in bulumario village is the leaf. The people of Bulumario still upholds the tribal value and customs. One of the tribal customs that is still applied by the people is the rule to not to harm the environment. This affects the plant utilization part, in which the leaf utilization will not damage the plant's growth. Most plant parts widely used by society is the leaf part, because it's easier to get whenever the community needs it [9]. Only few people of Bulumario who own plants at their yards, because the majority of them are farmers. They only plant for foods, medicine or livelihood plants in the farm. This makes the medicinal plants to be much more often found at the farm compared to the other places. Only a few medicinal plants are from another place such as the forest. One of them is "gagatanharimau" (Vitisgracilis). The people believe that gagatanharimauis a plant that is able to 
heal internal wound because this plant is a plant that is eaten by tigers if they are wounded or sick.

\section{CONCLUSION}

The Batak Angkola Subethnic in Bulumario Village is known to still preserve cultural values, one of which is the traditional use of medicinal plants. Proven from the presence of 65 plant species that are known to the public can treat various types of diseases.

\section{REFERENCES}

[1] Aththorick, T.A. \& L. Berutu. 2018. Ethnobotanical study and phytochemical screening of medicinal plants on Karonese people from North Sumatra, Indonesia. Journal of physic. Conf. Series 1116 (2018) 052008

[2] Balakumbahan, R., K. Rajamani\& K. Kumanan. 2010. Acoruscalamus: An overview. Journal of Medicinal Plants Research. 4(25): 2740-2745.

[3] Dey, P., S. Chandra, P. Chatterjee, S. Bhattacharya. 2011. Neuropharmacological properties of Mikaniascandens (L.) Willd. Journal of Advanced Pharmaceutical Technology \& Research. 2(4):255-259.

[4] Ersam, T., 2004, KeunggulanBiodiversitasHutanTropika Indonesia dalamMerekayasa Model MolekulkAlami, Seminar Nasional Kimia

[5] Farnsworth, N. R., O. Arkerele, A.S. Bingel, D. D. Soejarto\& Z. Guo. 1985. Medical plants in therapy. Bulletin of the word health organization. 63 (6): 965- 981.

[6] Kartawinata, K. 2010. Duaabadmengungkapkekayaan flora danekosistem Indonesia. Dalam: SarwonoPrawirohardjo Memorial Lecture X. LIPI. 23 Agustus 2010. Jakarta.

[7] Marpaung, D.R.A.K. 2018. Tumbuhanobatdankearifanlokalmasyarakat di sekitarkawasan TNBG DesaSibanggorJuluKabupatenMandailin Natal. JurnalBiosains. 4(2): 85-91.

[8] Muktiningsih, S.R., H.S. Muhammad, I.W. Harsana, M. Budhi\& P. Panjaitan. 2001. Review tanamanobat yang digunakanolehpengobattradisional di Sumatera Utara, Sumatera Selatan, Bali dan Sulawesi Selatan. Media LitbangKesehatan. 11(4): 25-36.

[9] Nurhaida, F.H. Usman\& G.E. Tavita. 2015. Sstudietnobotanitumbuhanobat di dusunKelampukKecamatan Tanah Pinoh Barat Kabupaten Melawi. JurnalHutan Lestari. 3(4): 526-537
[10] Purwadi, E. Kriswiyanti, Aliffiati, G.A.S. Wahyuni\& D.P. Ningsih. 2015.

Eksplorasipengetahuanlokaletnomedisindantumb uhanob atberbasiskomunitas di Indonesia. KementerianKesehatan RI

BadanPenelitiandanPengembanganKesehata.

[11] Silalahi, M., Nisyawati, E.B. Walujo\& W. Mustaqin. 2018. EtnomedisintumbuhanobatolehSubetnisBatakPha kpak di DesaSurungMersada, KabupatenPhakpak

Barat, Sumatera Utara. JurnalImuDasar. 19(2): $77-92$.

[12] Simanjuntak, H.A. 2016. Etnobotanitumbuhanobat di masyarakatEtnisSimalungunKabupatenSimalung unProvi nsi Sumatera Utara. BioLink. 3(1): 75 80.

[13] Supriatna, J. 2008. Melestarikanalam Indonesia. Jakarta: YayasanObor Indonesia.

[14] Simbolon, H. 1994. Ethnobotany of people around the DolokSibuak-buali Nature Reserve Area North Sumatera Indonesia. Tropics. 4(1): 69-78

[15] Winara, A. \& A.S. Mukhtar. 2016. Pemanfaatan tumbuhan obat oleh Suku Kanum di Taman Nasional Wasur Papua. Jurnal Penelitian Hutan dan Konservasi Alam.13(1): 57-72. 